\title{
PARASITIC NATURAL ENEMIES OF LEMON TREE BORER
}

\author{
Q. WANG and G. L. SHI ${ }^{1}$ \\ Plant Protection, Institute of Natural Resources, Massey University, \\ Private Bag 11122, Palmerston North \\ ${ }^{1}$ Current address: Department of Plant Protection, Shanxi Agricultural University, \\ Taigu County 030801, Shanxi, PRC
}

\begin{abstract}
In 1997 and 1998, a survey for natural enemies of the lemon tree borer, Oemona hirta (Fabricius), was conducted in the North Island of New Zealand. Citrus twigs with sign of lemon tree borer damage were collected in three locations (Gisborne, Kerikeri and Palmerston North). Two ichneumonid species [Xanthocryptus novozealandicus (Dalla Torre) and Campoplex sp.] and one braconid species (Apsicolpus hudsoni Turner) were recorded attacking larvae of lemon tree borer. $X$. novozealandicus attacked late instar larvae in shallow galleries and A. hudsoni and Campoplex sp. consumed early to middle instar larvae in deep galleries. Females of all three species laid female-producing eggs on larger host larvae. The overall parasitism rate for all three species was $<5 \%$ while the parasitism rate in a Gisborne orchard where no spraying had been conducted in the past five years was much higher: $29.5 \%, 18.2 \%$ and $6.8 \%$ for $X$. novozealandicus, Campoplex sp. and A. hudsoni, respectively.
\end{abstract}

Keywords: Cerambycidae, Oemona hirta, parasitoids, Xanthocryptus novozealandicus, Apsicolpus hudsoni, Campoplex.

\section{INTRODUCTION}

The lemon tree borer, Oemona hirta (Fabricius), is a native longicorn beetle in New Zealand. It has now become a pest of many introduced crops including citrus, apple, persimmon, grape, etc. and shelter belt trees, such as poplar (Miller 1925; Hudson 1934; Dumbleton 1937; Clearwater 1981; Spiller and Wise 1982; Rohitha et al. 1992). A female can lay over 50 eggs in her lifespan (Wang et al. 1998) and one or a few larvae can kill or severely weaken branches of trees and vines or may kill whole trees and vines once they enter the trunk.

The borer was first reported as a major pest of citrus trees in 1938 by Cottier. It is now distributed throughout the country but major damage to citrus occurs in the North Island, particularly in Northland and Gisborne regions. For example, the borer infested over $30 \%$ of 14,500 mixed citrus trees in a Gisborne orchard in 1997 (M. Smith, per. comm.). In recent years, serious damage has also occurred on other crops. For instance, in a Hamilton apple orchard, trees were so damaged that locals were talking about pulling the trees out in 1997 (C. Thomson, per. comm.). In the Mission Vineyard (Hawkes Bay), grapevines were almost 100\% infested in 1996 and two blocks of vines were pulled out in 1998. Therefore, this pest can be a prolonged threat to viability of various tree and vine crops.

Once larvae enter branches and trunks, chemical control becomes impractical. Biological control has thus attracted serious attention. This paper reports the results from a recent survey for natural enemies of the lemon tree borer.

\section{MATERIALS AND METHODS}

In 1997 and 1998, a total of 819 citrus twigs with damage signs and symptoms of O. hirta was collected in citrus orchards of Kerikeri, Gisborne and Palmerston North, where pesticides have been applied every year in the past five years. A further 51 borer- 
damaged twigs were collected in a Gisborne orchard, which had not been sprayed in the past five years. Individual twigs were put in $27 \times 45 \mathrm{~cm}$ permeable plastic bags (Cryovac, W.R. Grace, Auckland, New Zealand) in the Entomology and IPM Laboratory of Massey University at $23 \pm 1{ }^{\circ} \mathrm{C} ; 57 \pm 10 \% \mathrm{RH}$, and a photoperiod of 14:10 (L:D) h, with lighting provided by fluorescent lights. The parasitoid species were identified by Dr. J. Berry of New Zealand Arthropod Collection, Landcare Research in Auckland.

To determine the borer larval stages attacked by the different parasitoid species or different sexes of the same parasitoid species, the relationship between larval size and larval gallery width was investigated. A total of 300 twigs were randomly selected and dissected immediately after their arrival at the laboratory. The dissected twigs where borer larvae were found to be parasitised were restored with sticky tape and kept in above-mentioned permeable plastic bags to allow parasitoids to complete their lifecycle. A total of 210 larvae of different stages and their galleries were measured. Parameters measured included thorax width (widest part of the larval body) and gallery width (longer diameter of the cross section of the gallery where the larva was found).

For twigs from sprayed orchards, when parasitoid adults emerged, their species, sex, body length and (if female) ovipositor length were recorded or measured. At the point where the parasitoid cocoon was found, twig diameter, gallery width and gallery depth (distance between gallery and twig surface) were measured. A total of 64 parasitoid adults was recorded and measured from those orchards.

All twigs were dissected at the end of this study. A total of 476 living borers (including larvae, pupae and adults) were recorded for twigs from the sprayed orchards. Overall parasitism rate for each parasitoid species in all sprayed orchards $=$ the number of individuals of a parasitoid species (total number of living borers + total number of parasitoids). Parasitism rate for each parasitoid species in the unsprayed orchard was calculated separately. A total of 24 parasitoid adults and 20 living borers were obtained from this orchard.

Data for relationship between borer larval size and larval gallery width were subject to regression analysis. Other data were analysed using ANOVA. Rejection level was $P=0.05$.

\section{Parasitoid species}

\section{RESULTS}

The parasitoid species of the lemon tree borer found in this study include $X$. novozealandicus (Hymenoptera: Ichneumonidae: Phygadeuontinae) (Picture in Muggleston 1992), Campoplex sp. (Hymenoptera: Ichneumonidae: Campopleginae) (Fig. 1) and A. hudsoni (Hymenoptera: Braconidae: Helconinae) (Fig. 2). All these species are solitary larval parasitoids. X. novozealandicus was recorded in Kerikeri, Gisborne and Palmerston North, A. hudsoni in Kerikeri and Gisborne and Campoplex sp. in Gisborne. Campoplex sp. was recorded for the first time in this study as a parasitoid of the lemon tree borer.

\section{Relationship between borer larval size and gallery width}

The two hundred and ten larvae measured included a wide range of larval stages from early instar (as small as $5.0 \mathrm{~mm}$ long x $1.5 \mathrm{~mm}$ wide) to mature instar (as large as $35.6 \mathrm{~mm}$ long x $6.1 \mathrm{~mm}$ wide). Regression analysis indicated that larval gallery width was significantly correlated with thorax width $\left(\mathrm{R}^{2}=0.52 ; \mathrm{F}=220.98 ; \mathrm{df}=1\right.$, 208; P < 0.0001). Relationship between gallery width and larval thorax width for $O$. hirta is expressed as Thorax width $=0.33+0.53 \times$ Gallery width.

\section{Host larval stage, gallery width and depth, and species and sex of parasitoids}

Gallery width of host larvae attacked by $X$. novozealandicus was significantly greater than those of larvae attacked by Campoplex sp. and A. hudsoni, and females of all three species emerged from significantly wider galleries than their males $(\mathrm{F}=$ 157.34; df = 5, 58; $\mathrm{P}<0.0001)($ Table 1).

The ovipositor of $A$. hudsoni and Campoplex sp. was significantly longer than that of $X$. novozealandicus $(\mathrm{F}=381.79 ; \mathrm{df}=2,38 ; \mathrm{P}<0.0001)$ and the first two species could reach and parasitize host larvae in significantly deeper galleries than the latter species $(\mathrm{F}=100.71 ; \mathrm{df}=5,58 ; \mathrm{P}<0.0001)$ (Table 1$)$. 


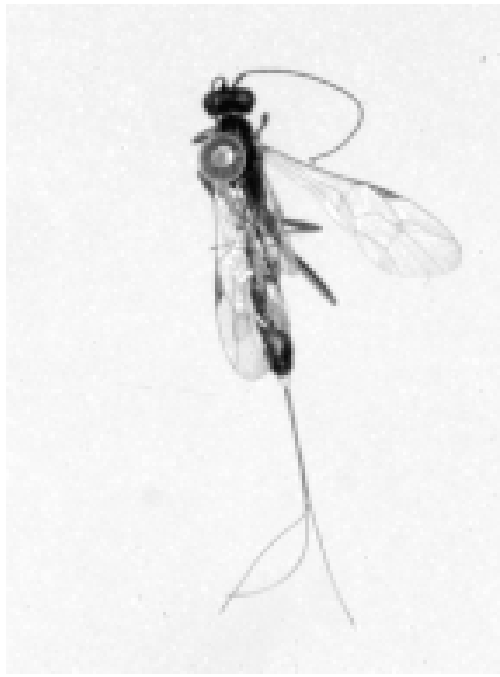

FIGURE 1: Female of Campoplex sp.

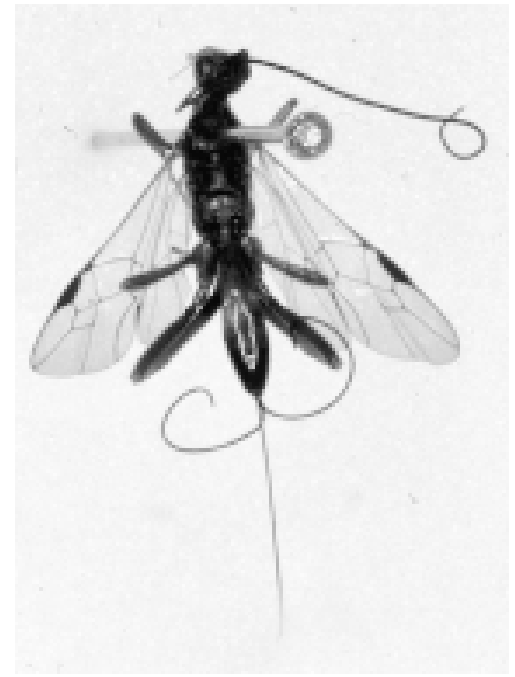

FIGURE 2: Female of Apsicolpus hudsoni.

\section{Parasitism rates}

The overall parasitism rates in the sprayed orchards were $4.26 \%, 3.89 \%$ and $3.70 \%$ for X. novozealandicus, Campoplex sp. and A. hudsoni, respectively. However, the parasitism rates in the unsprayed Gisborne orchard were much higher: $29.5 \%, 18.2 \%$ and $6.8 \%$ for $X$. novozealandicus, Campoplex sp. and A. hudsoni, respectively.

TABLE 1: Dimensions of lemon tree borer galleries and parasitoids.

\begin{tabular}{llcc}
\hline Species/Sex & Gallery width & $\begin{array}{c}\text { Mean }{ }^{1} \pm \mathrm{SD}(\mathrm{mm}) \\
\text { Gallery depth }\end{array}$ & $\begin{array}{c}\text { Ovipositior } \\
\text { length }\end{array}$ \\
\hline Campoplex $\mathrm{sp} . / \mathrm{female}$ & $5.60 \pm 0.28 \mathrm{a}$ & $5.93 \pm 0.51 \mathrm{a}$ & $8.05 \pm 0.22 \mathrm{a}$ \\
Campoplex $\mathrm{sp} . / \mathrm{male}$ & $4.11 \pm 0.53 \mathrm{~b}$ & $6.38 \pm 1.03 \mathrm{a}$ & \\
A. hudsoni/female & $5.57 \pm 0.23 \mathrm{a}$ & $6.45 \pm 0.59 \mathrm{a}$ & $8.85 \pm 0.32 \mathrm{a}$ \\
A. hudsoni/male & $4.54 \pm 0.25 \mathrm{bc}$ & $6.10 \pm 0.36 \mathrm{a}$ & $3.91 \pm 0.76 \mathrm{~b}$ \\
X. novozealandicus/female & $8.24 \pm 0.61 \mathrm{~d}$ & $2.98 \pm 0.32 \mathrm{~b}$ & \\
X. novozealandicus/male & $7.13 \pm 0.31 \mathrm{e}$ & $2.37 \pm 0.52 \mathrm{~b}$ & \\
\hline
\end{tabular}

${ }^{1}$ Means within columns with different letters are significantly different $(\mathrm{P}<0.05$, ANOVA)

\section{DISCUSSION}

All three parasitoid species are native to New Zealand but their geographic distribution varies. Campoplex sp. was found only in Gisborne. A. hudsoni is recorded in Gisborne and Kerikeri in the present study and was also found in Auckland by Dye in 1950. X. novozealandicus has a very wide distribution throughout New Zealand (Early 1984; Clearwater 1989).

The number of larval instars and the body size of different instars are not known for $O$. hirta. This study indicates there is a significant correlation between gallery width and larval body size, providing a practical tool for evaluation of relationship between borer larval stages and parasitoids. 
For all three parasitoid species, females are significantly larger than males, suggesting that females allocate the sex of offspring depending on the size of host larvae and lay female-producing eggs on significantly larger host larvae. This is common in many other parasitoid species (Sandlan 1979; Jones 1982; van den Assem et al. 1989). Charnov (1979) suggested that if hosts vary in size and the incremental gain in fitness per host is greater for one sex than for the other, then female parasitoids should allocate that sex to the larger hosts. In general, female parasitoids have more to gain in fitness from developing in a large host than do males (van Alphen and Jervis 1996) because major components of female fitness, the fecundity, are more strongly correlated with body size than those of males (van den Assem et al. 1989).

Campoplex sp. and A. hudsoni consume early to middle instar host larvae while $X$. novozealandicus attacks late instar larvae or pre-pupae (Table 1). This can simply be related to the amount of food required by each species, depending upon their body size. In many cases, if the host size exceeds the amount required by the parasitoid larva to complete its development, the parasitoid's survival may be reduced due to putrefaction of the remaining host tissues (van Alphen and Jervis 1996). Furthermore, ovipositors of A. hudsoni and Campoplex sp. were significantly longer than those of $X$. novozealandicus, suggesting that the first two species usually attack host larvae in significantly deeper galleries than the latter species (Table 1).

For $X$. novozealandicus, the parasitism rate varied between 3.6 and $13.1 \%$ (Dye 1950), and 0.8 and 26.4\% (Clearwater 1989) in the Auckland region but these authors did not mention the spray history of the orchards where parasitoids were collected. There have been no previous reports on parasitism rates for the other two species. During this study, the overall parasitism rate of any species from sprayed orchards did not exceed $5 \%$. However, the parasitism rates were much higher for all three parasitoid species from the unsprayed Gisborne orchard. This suggests that use of pesticides in orchards significantly reduced the number of parasitoids.

Other factors may affect parasitism rates. For example, even in the unsprayed orchard, parasitism rates are still not high enough to be effective in suppression of the borer population. Infestation rate was $100 \%$ in the orchard and branches of many trees had died or were dying. It is possible that these parasitoids are more microhabitatspecific than host-specific and as such they could not find most of their hosts in "wrong" habitats (such as orchards).

In conclusion, there is a potential to use these parasitoids for the suppression of the lemon tree borer population in orchards. However, their detailed host-finding behaviour needs investigation before they can be used for biological control.

\section{ACKNOWLEDGEMENTS}

We thank C. \& A. Lewis of Hemyock Orchards in Gisborne, M. Smith and W. Dooling of Waitaria in Gisborne and R. Duffy of Kwon in Kerikeri for collecting a large number of citrus twigs and providing relevant information for us; J. Berry of New Zealand Arthropod Collection, Landcare Research in Auckland for identifying the parasitoids; L. Davis and R. Johnston for their technical assistance, and C. Thomson of Hort-Research, Ruakura for information. We gratefully acknowledge financial support from Massey University Agricultural Research Foundation, Hemyock Orchards and Gisborne Citrus Growers Association.

\section{REFERENCES}

Charnov, E.L., 1979. The genetic evolution of patterns of sexuality: Darwinian fitness. Am. Nat. 113: 465-480.

Clearwater, J.R., 1981. Lemon tree borer, Oemona hirta (Fabricius), life cycle. DSIR Information Series, 105/33.

Clearwater, J.R., 1989. Oemona hirta (F.), lemon tree borer (Coleoptera: Cerambycidae), pp. 213-216. In: A Review of Biological Control of Invertebrate Pests and Weeds in New Zealand 1874-1987, Cameron, P.J., Hill, R.L., Bain, J. and Thomas, W.P. (Ed.). CAB International, UK.

Dumbleton, L.J., 1937. Borers in fruit trees. N.Z. J. Agric. 55: 295-298. 
Dye, M.H., 1950. Studies on the anatomy and biology of Oemona hirta Fabricius (Coleoptera: Cerambycidae). MSc thesis, Auckland University College, Auckland.

Early, J.W., 1984. Parasites and predators, pp. 271-380. In: New Zealand Pest and Beneficial Insects, R.R. Scott (ed.), Lincoln University College of Agriculture, Canterbury, New Zealand.

Hudson, G.V., 1934. New Zealand Beetles and their Larvae. W.A.G. Skinner, Wellington.

Jones, W.T., 1982. Sex ratio and host size in a parasitic wasp. Behav. Ecol. Sociobiol. 10: $207-210$.

Miller, D., 1925. Forest and timber insects in New Zealand. N.Z. State For. Serv. Bull. 2: $1-76$.

Muggleston, S., 1992. Bitter lemon - identification and control of lemon tree borer. Growing Today March: 42-43, 46.

Rohitha, B.H., Hartley, T. and Franklin, S.J., 1992. Lemon tree borer damage on persimmon. Proc. $45^{\text {th }}$ N.Z. Plant Prot. Conf.: 141-142.

Sandlan, K., 1979. Sex ratio regulation in Coccygomimus turionellae Linnaeus (Hymenoptera: Ichneumonidae) and its ecological implications. Ecol. Entomol. 4: 365-378.

Spiller, D.M. and Wise, K.A.J., 1982. A catalogue of New Zealand insects and their host plants. N.Z. Dep. Sci. Ind. Res. Bull. 213: 1-259.

Van Alphen, J.J.M. and Jervis, M.A., 1996. Foraging behaviour. Pp. 1-62. In: Insect Natural Enemies. M. Jervis and N. Kidd (ed.). Chapman \& Hall, London.

Van den Assem, J., van Iersal, J.J.A. and los den Hartogh, R.L., 1989. Is being large more important for female than for male parasitic wasps? Behaviour 108: 160195.

Wang, Q., Shi, G. and Davis, L.K., 1998. Reproductive potential and daily reproductive rhythms of Oemona hirta (Coleoptera: Cerambycidae). J. Econ. Entomol. 91: 1360-1365. 